\title{
The distribution of fibrolytic activity in the rumen of ciliate-free and faunated sheep
}

\author{
T. Michałowski ${ }^{\mathrm{C}}$ \\ The Kielanowski Institute of Animal Physiology and Nutrition, Polish Academy of Sciences \\ 05-110 Jabtonna, Poland
}

\begin{abstract}
The aim of this study was to determine the ruminal fibrolytic activity in defaunated and selectively faunated sheep. After defaunation, xylanase activity was 25-31 while carboxymethylcellulase (CMCase), $2.5 \mu \mathrm{M}$ reducing sugars $/ \mathrm{g} \mathrm{DM} / \mathrm{min}$. As much as $73-81 \%$ of xylanase and $84-96 \%$ of CMC-ase in defaunated sheep originated from particle-associated bacteria. Ciliates increased the activity of xylanase to about $90-95$ and $\mathrm{CMC}$-ase to $4.7 \mu \mathrm{M}$ reducing sugars/g. As much as $74-80 \%$ of total xylanase and $61-62 \%$ CMC-ase in faunated animals originated from the ciliate, Eudiplodinium maggii. Ciliates did not negatively influence the colonization of feed particles by bacteria.
\end{abstract}

KEY WORDS: rumen content, particulate matter, protozoa, $\beta$-endoglucanase, xylanase

\section{INTRODUCTION}

Fibre degradation in the rumen depends on microorganisms able to synthesize cellulolytic and hemicellulolytic enzymes. It is known that predominant fibrolytic bacteria and fungi colonize fibrous particles (Mc Allister et al., 1994) while ciliates do not (Williams and Coleman, 1992). It is also well documented that protozoa diminish the numbers of bacteria and fungal zoospores in the rumen fluid (Williams and Coleman, 1992). Thus they can influence the colonization of fibrous feed by two other groups of microorganisms. The aim of this study was to determine the activity of carboxymethylcellulsae (CMC-ase) and xylanase in whole rumen digesta, as well as in the particulate and liquid fractions with respect to the absence and presence of ciliates.

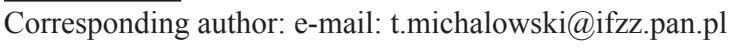




\section{MATERIAL AND METHODS}

Two adult female Black Head rumen-fistulated sheep were kept in separate pens and fed $150 \mathrm{~g}$ of pelleted concentrate (17\% crude protein) at 8 and $16 \mathrm{~h}$. Meadow hay and drinking water were given ad libitum. Samples of rumen contents were collected three times a day on the 10, 11 and 12 day after defaunation (Jouany and Senaud, 1979) as well as on the 22, 24, 26, 28 and $30 \mathrm{~d}$ after spontaneous refaunation of animals. The particulate fraction was prepared by rinsing rumen digesta with tap water on a screen of pore size $0.5 \mathrm{~mm}$, while the liquid fraction, by squeezing the rumen content and centrifuging the obtained fluid for $4 \mathrm{~min}$ at $500 \times \mathrm{g}$ and $4^{\circ} \mathrm{C}$. The protozoa were purified and separated into Entodinium maggii and "small ciliates" groups by a sedimentation method (Michałowski, 1990). Crude enzymes were extracted with $\mathrm{CCl}_{4}$ at $40^{\circ} \mathrm{C}$ for 4 $\mathrm{h}$ according to Huhtanen and Khalili (1992). The activity of CMC-ase and xylanase was determined by quantification of the reducing sugars released from carboxymethylcellulose and xylan incubated at $40^{\circ} \mathrm{C}$ for $1 \mathrm{~h}$ with crude enzymes. Reducing sugars were measured using 3,5-dinitrosalicylic acid (Miller et al., 1960). The protozoa were counted using a light microscope.

\section{RESULTS AND DSCUSSION}

The total fibrolytic activity in the rumen resulted either from the presence of bacteria or bacteria and the re-established protozoa, because fungi did not develop after defaunation of sheep. The spontaneously re-established ciliate

Table 1. Enzyme activities in the rumen content and its two fractions ( $\mu \mathrm{M}$ released reducing sugars/g DM rumen content and particulate fraction or $\mathrm{ml}$ of liquid fraction) of defaunated and spontaneously refaunated sheep

\begin{tabular}{|c|c|c|c|c|}
\hline \multirow{2}{*}{ Enzymes } & \multicolumn{2}{|c|}{ Sheep 1} & \multicolumn{2}{|c|}{ Sheep 2} \\
\hline & defaunated & refaunated & defaunated & refaunated \\
\hline \multicolumn{5}{|c|}{ Whole rumen content } \\
\hline xylanase & $30.7 \pm 10.67$ & $94.8 \pm 8.37 * *$ & $25.0 \pm 4.11$ & $90.3 \pm 10.50^{* *}$ \\
\hline CMC-ase & $2.5 \pm 0.50$ & $4.7 \pm 0.93^{* *}$ & $2.5 \pm 0.29$ & $4.7 \pm 0.87 * *$ \\
\hline \multicolumn{5}{|c|}{ Particulate fraction } \\
\hline xylanase & $22.3 \pm 5.53$ & $22.1 \pm 3.44$ & $20.4 \pm 3.27$ & $20.4 \pm 7.03$ \\
\hline CMC-ase & $2.4 \pm 0.16$ & $2.1 \pm 0.24$ & $2.1 \pm 0.25$ & $2.3 \pm 0.55$ \\
\hline \multicolumn{5}{|c|}{ Liquid fraction } \\
\hline xylanase & $0.5 \pm 0.11$ & $0.4 \pm 0.07$ & $0.3 \pm 0.06$ & $0.2 \pm 0.05$ \\
\hline CMC-ase & $0.08 \pm 0.02$ & $0.07 \pm 0.01$ & $0.07 \pm 0.01$ & $0.05 \pm 0.01$ \\
\hline
\end{tabular}

$* * \mathrm{P}<0.01$ 
species were Eudiplodinium maggii, Entodinium simplex and Dasytricha ruminantium. The last two reappeared in the rumen of only one sheep. The significant increase in the activity of xylanase and CMC-ase resulted from the establishment of fibrolytic ciliates Eudiplodinium maggii (Coleman, 1985). These ciliates clearly determined the fibrolytic activity in the rumen of both sheep (Table 2). No differences were found between the particleassociated activity in the ciliate-free and refaunated sheep and this suggests that establishment of protozoa did not restrict the colonization of feed particles by fibrolytic bacteria (Silva et al., 1987), at least as far as particles larger than 0.5 $\mathrm{mm}$ are concerned. These results are contradictory to the findings of Newbold et al. (1989). However, the effect of fauna composition should be taken into consideration during such a comparison. The very low CMC-ase and xylanase activity in the liquid fraction of the rumen digesta confirms the opinion that the majority of fibrolytic bacteria is tightly associated with the particles of forages (McAllister et al., 1994).

Table 2. Ciliate number in the rumen of the spontaneously refaunated sheep and their contribution to the total activity of CMC-aze and xylanase, $\%$ of total ruminal activity

\begin{tabular}{lcc}
\hline Item & Sheep 1 & Sheep 2 \\
\hline Total CMC-ase, $\mu \mathrm{M}$ reducing sugars/g DM/min & $94.8 \pm 8.3$ & $90.3 \pm 10.50$ \\
Eudiplodinium maggii numbers, $\times 10^{3} / \mathrm{g}$ digesta & $36.8 \pm 12.01$ & $35.5 \pm 8.33$ \\
Eudiplodinium maggii xylanase, \% of total value & $73.7 \pm 5.12$ & $79.8 \pm 4.91$ \\
Eudiplodinium maggii CMC-ase, \% of total value & $62.2 \pm 3.72$ & $61.1 \pm 4.59$ \\
Small ciliate numbers, $\times 10^{3} / \mathrm{g}$ digesta & 0.0 & $198.4 \pm 73.23$ \\
Small ciliate xylanase, \% of total value & $\mathrm{ND}$ & $1.5 \pm 0.28$ \\
Small ciliate CMC-ase, \% of total value & $\mathrm{ND}$ & $3.1 \pm 0.49$ \\
\hline
\end{tabular}

ND - not determined

The ciliates appeared spontaneously in the rumen as early as about 3 weeks after defaunation and this suggests that the applied defaunation procedure was unsuccessful. Of the re-established species, Entodinium simplex and Dasytricha ruminantium belonging to the group "small ciliates" were present in the rumen of only one sheep. The fibrolytic activity detected in these protozoa originated presumably from the engulfed bacteria since the both species are unable to digest cellulose (Williams and Coleman, 1992).

\section{CONCLUSIONS}

In the ciliate-free sheep, the activities of CMC-ase and xylanase originated predominantly from bacteria colonizing the particulate fraction of rumen contents while in the refaunated animals, from the fibrolytic ciliate, Eudiplodinium maggii. 
The obtained data also suggest that the appearance of ciliates in the rumen of sheep did not diminish the colonization of feed particles by fibrolytic bacteria.

\section{REFERENCES}

Coleman G.S., 1985. The cellulase content of 15 species of entodiniomorphid protozoa, mixed bacteria and plant debris isolated from the ovine rumen. J. Agr. Sci. 104, 349-360

Huhtanen P.P., Khalili H., 1992. The effect of sucrose supplement on the particle-associated carboxylethylcellulase (EC 3.2.1.4) and xylanase (EC 3.2.1.8) activities in cattle given grasssilage-based diet. Brit. J. Nutr. 67, 245-255

Jouany J.-P., Senaud J., 1979. Defaunation du rumen de mounton. Ann. Biol. Anim. Biochem. Biophys. 19, 619-624.

McAllister T.A., Bae H.D., Jones G.A., Cheng K.-J., 1994. Microbial attachment and digestion in the rumen. J. Anim. Sci. 56, 1235-1244

Michałowski T., 1990. The synthesis and turnover of the cellular matter of ciliates in the rumen. Acta Protozool. 29, 47-92

Miller G.L., Blum R., Glennnon W.E., Burton A.L., 1960. Measurement of carboxymethylcellulase activity. Anal. Biochem. 2, 127-132

Newbold C.J., Griffin W.P., Wallace R.J., 1989. Interaction between bacteria and ciliate protozoa in their attachment to barley straw. Lett. Appl. Microbiol. 8, 63-66

Williams A.G., Coleman G.S., 1992. The Rumen Protozoa. Springer-Verlag. New York

\section{STRESZCZENIE}

\section{Dystrybucja aktywności fibrolitycznej w żwaczu owiec wolnych od orzęsków i selektywnie faunowanych}

Celem badań było określenie aktywności enzymów fibrolitycznych w żwaczu owiec zdefaunowanych i selektywnie faunowanych. Stwierdzono, że po defaunacji aktywność ksylanazy wynosiła 25-31, a karboksymetylocelulazy (CMC-azy) - $2.5 \mu \mathrm{M}$ cukrów redukujących/mg s.m./ min. Około 73-81\% ogólnej aktywności ksykanazy i 84-96\% aktywności CMC-azy pochodziło z bakterii kolonizujących cząstki stałe paszy. Orzęski spowodowały wzrost aktywności ksylanzay do 90-95 i CMC-azy do 4,7 $\mu$ M cukrów redukujących/mg s.m./min. Stwierdzono, że 74-80\% ogólnej aktywności ksylanazy w żwaczu i 61-62\% aktywności CMC-azy pochodziło z komórek orzęsków Eudiplodinium maggii. Wykazano, że orzęski nie miały ujemnego wpływu na kolonizację cząstek paszy przez bakterie. 